\title{
Transport and Land Use in China
}

\author{
Introduction to the Special Issue
}

\section{P. Christopher Zegras \\ Massachusetts Institute of Technology ${ }^{\text {a }}$}

Perhaps no developing country better represents the challenges and opportunities posed by the forces of urbanization in this century than China. The country is undergoing a major demographic transition of rapid and intense urbanization. China already has more than 100 cities with populations over one million, but only 45 percent of its total population currently lives in urban areas-this share will increase to 60 percent over the next 20 years (United Nations 2008). This basic demographic force-combined with economic reforms and restructuring, fiscal decentralization, and changing consumer expectations with respect to residential space, consumer products, and the like-are dramatically transforming the Chinese urban landscape. Cities are undergoing rapid expansion in physical size as their population densities fall. In the greater Beijing mega-region (Beijing-Tianjin-Hebei), for example, the built-up area increased by 71 percent during the 1990s, more than double the population growth rate, with most of this growth occurring on arable land (Tan et al. 2005). Similar trends are seen elsewhere in the country (e.g. Zhao et al. 2007).

At the same time, China has already become the world's single largest emitter of greenhouse gases (GHG) due to its energy consumption (International Energy Agency 2010) and the single largest manufacturer of both automobiles and commercial vehicles (International Organization of Motor Vehicle Manufacturers 2010). Yet the country is still in the early stages of motorization, with just 32 vehicles per thousand persons in 2007, compared to 595 per thousand persons in Japan and 820 in the United States (World Bank 2010). As China's vehicle manufacturing industry becomes increasingly sophisticated and competitive, vehicle prices in China (and likely in the rest of the world as well) will decline, further fueling consumer demand for private motor vehicles.

Where will the combination of these massive, interacting forces take urban China's land use and transportation systems? In his historical review of the interactions between transportation system developments and intra-metropolitan growth patterns in the United States, Muller (2004) identifies four different "eras," within which the role of the predominant transportation technology of the time distinctly shapes the land use patterns: the "Walking-Horsecar Era," the "Electric Streetcar Era," the "Recreational Automobile Era," and the "Freeway Era." Substituting the bicycle for the "Walking-Horsecar Era," we can see that China seems to be compressing these four eras into a single hybrid. Both in anticipation of and to further strengthen domestic motor vehicle demand, China has embarked on a massive highway construction program, with an estimated 53,000 km of expressways built as of 2007 (compared to 75,000 km in the United States) (United States Central Intelligence Agency 2010). Interestingly, the country has also

\footnotetext{
aczegras@mit.edu
} 
almost simultaneously embarked on the world's largest high speed rail investment program, and an aggressive expansion of urban public transportation systems, including rail transit and bus rapid transit (BRT). And, of course, China comes from a relatively recent tradition of being one of the most bicycle-dominated transportation systems in the world.

This issue of the Journal of Transport and Land Use offers a snapshot of the interactions between land use and transportation systems in China at three different scales of analysis. In the first paper, Ng, Schipper, and Chen take a macro-level perspective, showing graphically how China's "business-as-usual" motorization trend threatens to overwhelm the nation's cities in terms of space consumption, air pollution, energy security, congestion, etc. While these challenges are not new to the world per se, the rate of growth (in income, number of private vehicles, demand for space, etc.) is occurring in very dense settlements could well collapse the system due to a fundamental lack of space. The authors argue that a multi-pronged suite of tools, pursuing everything from proper vehicle size and engine technology to road pricing and other demand management measures, will provide the only viable pathway.

In the second paper, Næss focuses on a particular metropolitan area and a specific question: does relative location in a mid-size Chinese city influence household travel energy use? Following in the long tradition of research on the relationship between the built environment and travel behavior, Næss uses data from a purpose-specific travel survey and shows a statistically significant positive relationship between dwelling unit distance to the city center and individuals' average daily transportation energy use. Næss at least partially attempts to control for the "self-selection" challenge (e.g. Mokhtarian and Cao 2008) by the inclusion of attitudinal and preference controls in his models. The results suggest that the "compact" metropolis in China would be less energy-intensive for an individual's daily travel, yet the challenge remains of how to realize such an urban form in practice.

Finally, Tao, Mehndiratta, and Deakin take us down to a street-level view, examining the relationship between pedestrian activity and street design in the mid-sized city of Fushun. The authors find a high apparent willingness of pedestrians to cross, unprotected, at mid-block behaviors which the authors attribute, at least in part, to the design of the walking environment. These findings lead the authors to suggest that China must take advantage of the rapid growth underway, and effectively integrate pedestrian planning into the basic bones of the city. Ultimately, the treatment of pedestrians in cities like Fushun may provide a microscopic view of how the great land use-transportation evolution plays out across the Chinese urban landscape.

\section{References}

International Energy Agency. 2010. Co2 emissions from fuel combustion - highlights, 2010 edition. URL http://www.iea.org/co2highlights/CO2highlights.pdf.

International Organization of Motor Vehicle Manufacturers. 2010. 2009 production statistics. URL http://www.oica.net/category/production-statistics/.

Mokhtarian, P. and X. Cao. 2008. Examining the impacts of residential self-selection on travel behavior: A focus on methodologies. Transportation Research B, 42:204-228.

Muller, P. 2004. Transportation and urban form: Stages in the spatial evolution of the American metropolis. In S. Hanson, ed., The Geography of Urban Transportation, pp. 59-85. Guildford Press, 3 edition. 
Ng, W.-S., L. Schipper, and Y. Chen. 2010. China motorization trends: New directions for crowded cities. The Journal of Transport and Land Use, 3(3):5-25. doi: 10.5198/jtlu.v3i3.151.

Næss, P. 2010. Residential location, travel, and energy use in the Hangzhou metropolitan area. The Journal of Transport and Land Use, 3(3):27-59. doi: 10.5198/jtlu.v3i3.98.

Tan, M., X. Li, H. Xie, and C. Lu. 2005. Urban land expansion and arable land loss in China: A case study of Beijing-Tianjin-Hebei region. Land Use Policy, 22(3):187-196.

Tao, W., S. Mehndiratta, and E. Deakin. 2010. Compulsory convenience? How large arterials and land use affect midblock crossing in Fushun, China. The Journal of Transport and Land Use, 3(3):61-82. doi: 10.5198/jtlu.v3i3.110.

United Nations. 2008. World urbanization prospects: The 2007 revision. URL http://data. worldbank.org/data-catalog/world-development-indicators.

United States Central Intelligence Agency. 2010. The world factbook. Updated 9 December 2010, URL https://www.cia.gov/library/publications/the-world-factbook/.

World Bank. 2010. World development indicators. Updated December 2010.

Zhao, H., Z.Zhang, and L. Jiang. 2007. Analysis and modeling on the spatial structure of urban land use: A case of Jinan, China. Chinese Journal of Population, Resources and Environment, $5(2): 34-40$. 